In Santander we were entertained by Prof. Diaz Caneja.

We were shown round the hospital and nurses' training school at Valdecilla, and saw the professor's method of examination of the fundi in red light to decrease the vascular markings and show up pigment.

On our return by way of Paris, we were met by Dr. Miller and shown over his new clinic at Montfermeil, where a full operating session had been arranged.

\title{
Ophthalmological Society of EgYPT
}

Annual Meeting, 1956.

THE annual meeting will take place at the Memorial Ophthalmic Laboratory, Giza, on March 16 and 17, 1956. A symposium will be held on corneal grafting. All medical practitioners, oculists or otherwise, are cordially invited to attend.

\section{HoNOuRs}

Mr. K. C. Wybar received the degree of Ch.M. (with high commendation) at Glasgow University on July 9, 1955.

\section{OBITUARY}

\section{Harold Pace GibB}

Harold Pace Gibb, M.B., B.Ch. Camb., F.R.C.S. Eng., died at the age of 77, on November 21, 1955. Educated at St. Paul's School and Sydney Sussex College, Cambridge, where he was a science exhibitioner, he entered St. Bartholomew's Hospital after gaining a first class science tripos. He qualified M.R.C.S. in 1904 and became a fellow in 1906. He was house surgeon to D'Arcy Power and later house physician at the Brompton and Queen Square Hospitals. At the latter he developed a keen interest in neurology which persisted throughout his life. He was fortunate in becoming clinical assistant to Sir John Parsons at Moorfields, and early in 1914 was appointed to the staffs of the West London and Central London Ophthalmic Hospitals. When war broke out he tried to enlist, but being rejected because of his profession joined the R.A.M.C. and served throughout the war as an ophthalmologist in Mesopotamia and in France. He retired from the West London Hospital in 1937 and was due to retire from the Central London Hospital in 1939, but because of staff shortage he came up from Gerrard's Cross and attended practically every out-patient session during the war, and carried on until 1947.

As a diagnostician, Harold Gibb was unique. Having the gift of a marvellous memory, he carried in his mind an index of ophthalmic literature extending over many years, to which he could refer when consulted on an abstruse case. His kindly understanding and gentleness with patients, particularly hospital patients, endeared him to all who knew him or benefited from his ministrations. He was a very genuine person who hated any kind of sham, medical, social, or religious. Being very forthright, he could not conceal disapproval, which he expressed in no uncertain terms when occasion demanded.

He played cricket for St. Paul's during his last two years at the school, and he was an outstanding golfer, though, in spite of being in the plus class, he never bothered to get a handicap. Antiques, especially prints, furniture, and pictures, were his delight, and he was a great student of history. He could have risen to the top of practically any profession he embraced, and was for 30 years an underwriting member of Lloyds, an unusual activity for a surgeon.

So passes, almost unnoticed, an exceptional man-a truly gentle man-unnoticed because of his extreme modesty, one of the old school who was exclusively a clinician.

J. D. M. CARdell 